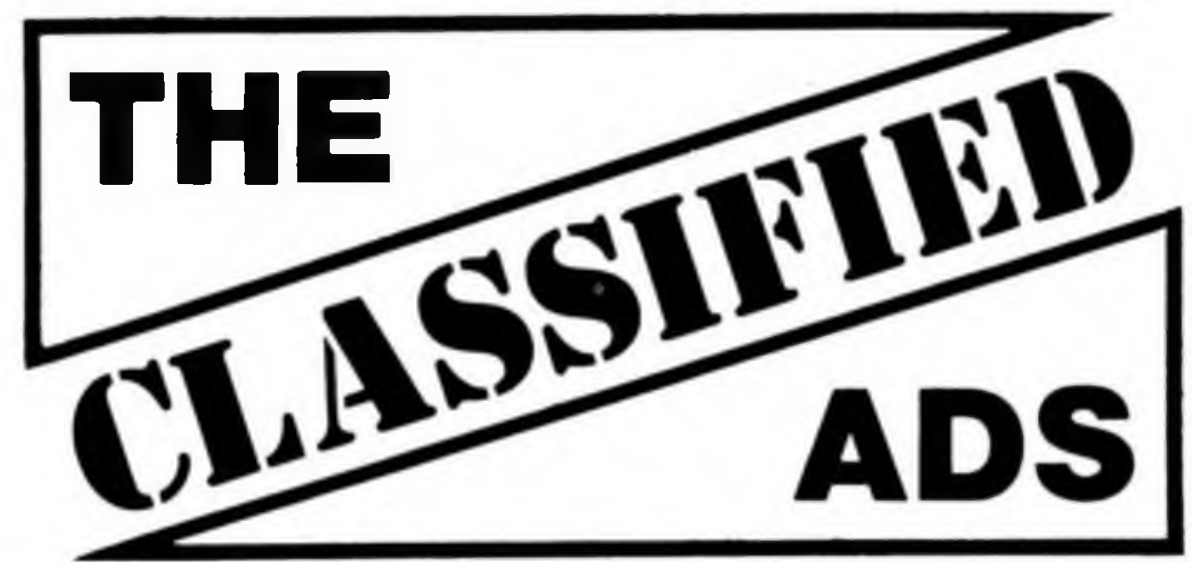

Deadlines: Orders for regular classified advertisements must reach the ACRL office on or before the second of the month preceding publication of the issue (e.g. September 2 for the October issue). If the second falls on a weekend, the deadline is the following Monday. Late job listings will be accepted on a space-available basis after the second of the month.

Rates: Classified advertisements are $\$ 5.25$ per line for ACRL members, $\$ 6.60$ for others. Late job notices are $\$ 12.60$ per line for members, $\$ 14.70$ for others. Organizations submitting ads will be charged according to their membership status.

Telephone: All telephone orders should be confirmed by a written order mailed to ACRL headquarters as soon as possible. Orders should be accompanied by a typewritten copy of the ad to be used in proofreading. An additional $\$ 15$ will be charged for ads taken over the phone (except late job notices or display ads). Ads may also be sent by FAX machine, (312) 440-9374, or by ALANET (ALA0306).

Guidelines: For ads which list an application deadline, that date must be no sooner than the 20th day of the month in which the notice appears (e.g. October 20 for the October issue). All job announcements should include a salary figure. Job announcements will be edited to exclude discriminatory references. Applicants should be aware that the terms faculty rank and status vary in meaning among institutions.

JOBLINE: Call (312) 944-6795 for late-breaking job ads for academic and research library positions. A pre-recorded summary of positions listed with the service is revised weekly; each Friday a new tape includes all ads received by $1.00 \mathrm{p} . \mathrm{m}$. the previous day. Each listing submitted will be carried on the recording for two weeks. The charge for each two-week listing is $\$ 30$ for ACRL members and $\$ 35$ for non-members.

Fast Job Listing Service: A special newsletter for those actively seeking positions. This service lists job postings received at ACRL headquarters four weeks before they appear in C\&RL News, as well as ads which, because of narrow deadlines, will not appear in $C \& R L$ News. The cost of a six-month subscription is $\$ 10$ for ACRL members and $\$ 15$ for non-members.

Contact: Classified Advertising Dep't, ACRL, American Library Association, 50 E. Huron St., Chicago, IL 60611; (312) 944-6780.

\title{
POSITIONS OPEN
}

\begin{abstract}
ACCESS SERVICES LIBRARIAN. Supervises circulation, audiovisual, preservation and Interlibrary loan. Participates in reference and bibliographic instruction. MLS required. Second Master's or doctorate necessary for tenure. Science background helpful. Minimum salary $\$ 25,000$. Send resume to: Donna Nickerson, Chair, Library Search Committee, Manhattanville College, 125 Purchase Street Purchase, NY 10577. Equal Opportunity Employer.
\end{abstract}

CATALOG LIBRARIAN. Responsibilities: Performs copy and original cataloging on OCLC in all bibliographic formats (primarily monographs and serials); assigns LCSH subject headings and classification numbers (Dewey and LC) as needed. Performs catalog maintenance and attends committee meetings for LUMIN, university-wide online public access catalog. Works in coordination with Head of Cataloging to devise cataloging procedures and solve complex bibliographic problems. Requirements: Master's degree in Library Science from an ALA-accredited school. Course work in cataloging and classification required and some library experience preferred. Salary: $\$ 19,000-+$. Send resumes and names and phone numbers of three references to: Search Committee for Catalog $\mathrm{Li}$ brarian, Curtis Laws Wilson Library, University of Missouri-Rolla, Rolla, MO 65401. Closing date: November 25, 1988. AA/EEO.

CHIEF BIBLIOGRAPHER. The University of Alabama Libraries, Tuscaloosa, invite applications for the position of Chief Bibliographer. This position reports to the Associate Dean of Libraries for Collections and Information Services and is responsible for planning, implementing, monitoring, coordinating, and evaluating the collection development program in an evolving environment. Reference and other librarians (22) are in the process of developing collection skills, activities, procedures, and policies under the leadership of this position. Qualifications: Required: MLS from a program accredited by ALA; additional graduate degree; relevant experience in a large research library; excellent oral and written communications skills; knowledge of publishing, book trade, higher education, and budget management; knowledge of issues and trends in bibliographic control, collection assessment and collection management; experience in management of approval plans; demonstrated skill in planning, organizing, and coordinating work of others; ability to work effectively and productively with faculty, students, and with library personnel at all levels; skill in developing, analyzing, and interpreting relevant statistical data; ability to function effectively in a changing environment and evidence of professional and/or scholarly activity. Preferred Working kriowledge of one or more foreign languages; experience with automated system, particularly in acquisitions; familiarity with RLG Conspectus. Twelve month, tenure earning position. Salary and rank depend on qualifications: Assistant or associate professor

\section{Salary guide}

Listed below are the minimum starting salary figures recommended by 16 state library organizations for professional library posts in these states. Job seekers and employers should consider these recommended mimumums, as well as other salary surveys (such as the survey in the October 15, 1987, issue of Library Journal, the ALA Survey of Librarian Salaries, the annual ARL Salary Survey, or the annual CUPA Administrative Compensation Survey) when evaluating professional vacancies. For more information, contact the ALA Office for Library Personnel Services.

\begin{tabular}{lr}
$\begin{array}{l}\text { Connecticut } \\
\text { Indiana }\end{array}$ & $\$ 22,200$ \\
lowa & varies* \\
Kansas & $\$ 18,792$ \\
Louisiana & $\$ 17,500^{*}$ \\
Maine & $\$ 20,000$ \\
Massachusetts & varies* \\
New Hampshire & $\$ 20,000$ \\
New Jersey & $\$ 17,500$ \\
New York & $\$ 20,350$ \\
North Carolina & varies* \\
Ohio & $\$ 20,832$ \\
Pennsylvania & $\$ 20,024$ \\
Rhode Island & $\$ 18,000$ \\
Vermont & $\$ 20,000$ \\
West Virginia & $\$ 18,500$ \\
\hline
\end{tabular}

${ }^{\star}$ Rather than establish one statewide salary minimum, some state associations have adopted a formula based on such variables as comparable salaries for public school teachers in each community or the grade level of a professional librarian post. In these cases, you may wish to contact the state association for minimum salary information.

rank, $\$ 27,000$ minimum salary, which includes an administrative stipend. Send cover letter, resume, and names and addresses of three references to: Sondra Tucker, Libraries Personnel Officer, The Uni- 
versity of Alabama, Collection Development Search, Main Library, P.O. Box 870266, Tuscaloosa, AL 35487-0266, by December 20 , 1988. The University of Alabama is an Equal Opportunity, Affirmative Action Employer.

CORPORATE INFORMATION LIBRARIAN. Librarian I or II. At the Harvard Business School, will be in charge of Baker Library's two outstanding collections of corporate information-the Career Resources Center (CRC) and the Corporate Reports Department. CRC acts as a clearinghouse, providing MBA students and HBS alumni with information about companies, industries, career planning, and specific job opportunities. The Corporate Reports Department maintains an extensive and heavily-used collection of domestic and foreign annual reports and SEC filings. In addition, this department is responsible for the library's microform collection. Supervises a staff of three plus many student assistants. Qualifications: ALAaccredited MLS degree or equivalent: 3 to 5 years professional experience. Ability to work effectively with people both individually and in groups; ability to handle a diversified range of tasks and perform well under pressure. Strong supervisory experience needed. Familiarity with corporate information sources. Rank: Librarian I or II. Salary: $\$ 20,600$, Librarian I (minimum); $\$ 24,560$, Librarian II (minimum), negotiable based on qualifications and experience. Available January 1, 1989. Applications to: Emma B. Perry, Associate Librarian for Administration, Baker Library, Harvard University, Soldiers Field Road, Boston, MA 02163. An Equal Opportunity, Affirmative Action Employer

DIRECTOR OF LIBRARIES, University of Georgia. The University of Georgia is seeking a person with proven leadership ability for the position of Director of Libraries. The Director is the chief executive officer for the Main Library, the Science Library, and several reading rooms and experiment station libraries. The combined holdings of these libraries and the separately-administered Law Library total 2.7 million volumes and 3.8 million microforms. The Director of this highly centralized system serves as an advocate of the Libraries within the University, articulates and frames the future of the Libraries, and participates in the national dialogue on research library concerns. The Director reports to the Vice President for Academic Affairs, participates in the Deans' Council, and is a member of the University Council, the educational policy-making body for the University. A land-grant university and the major institution in the State University System, the University of Georgia has an enrollment of 27,000 students in 13 schools and colleges. The Libraries' budget for 1988-89 is approximately $\$ 10$ million, and the staff of 252 in cludes 70 librarians. The Libraries' integrated automation system supports acquisitions, circulation, and an online catalog. The University of Georgia is a member of the Association of Research Libraries, the Center for Research Libraries, and SOLINET. Qualifications: A master's degree in library science from an ALA-accredited school; extensive and progressively more responsible experience in the management of a large academic or research library; a strong com mitment to the research, instruction, and service missions of a university; excellence in leadership; effective communication and interpersonal skills; and an extensive knowledge of current issues, information technologies, and automated library systems. Salary: Commensurate with experience, $\$ 80,000$ minimum. Send nomination or letter of application, curriculum vitae, and names and ad dresses of four references to: Director of Libraries Search Committee, 110 Old College, University of Georgia, Athens, GA 30602 Application deadline is January 2, 1989. Preference is to fill the position no later than September 1, 1989. The University of Georgia is an Equal Opportunity, Affirmative Action Institution.

DIRECTOR OF LIBRARY. Winona State University invites applications for this position. The starting date is negotiable and the current salary range is $\$ 36,687-\$ 58,297$. Responsibilities: The Director is responsible for the overall management and development of library services, collections, budgets, and staff. Qualifications: The Director must be a strong leader with demonstrated administrative and managerial skills in an online environment, a strong service orientation, understanding of current trends in academic information management systems, and the ability to provide direction in the application of new technologies to library operations. ALA-accredited master's is required; a second master's or Ph.D. preferred. A minimum of five years, experience in Library Administration. Preference will be given to candidates with demonstrated significant experience in budget management. Application: Send resume, transcripts, and three letters of reference to: Library Director Search, Office of Human Resources, Winona State University, Winona, MN 55987. Open until

\section{Assistant Chief}

The Stanford University Libraries seek an Assistant Chief, Access Services Department responsible for planning, management and supervision of Department's Loan and Privileges Divisions, coordination of Department computer services and public information program and administration of use of study spaces within the Cecil $\mathrm{H}$. Green Library. Assists Chief in administrative duties and will be in charge of Department in Chief's absence.

Qualifications: MLS or equivalent. Effective communication, human relations and organizational skills. Public service experience in a research library. Supervisory experience required; management of a large unit preferred. Experience with library automation applications required and with automated circulation systems preferred. Background in systems analysis, public relations or editing desirable. Associate Librarian $(\$ 29,700-41,400)$ or Librarian $(\$ 33,900-50,000)$, rank dependent on qualifications. Send letter of application, resume and names and addresses of 3 professional references by December 9, 1988 to Irene Yeh, Assistant Library Personnel Officer, Stanford, CA 94305 . 6004. Cite \#331$\mathrm{CRL}$, on all corre-

spondence. EEO/AAE

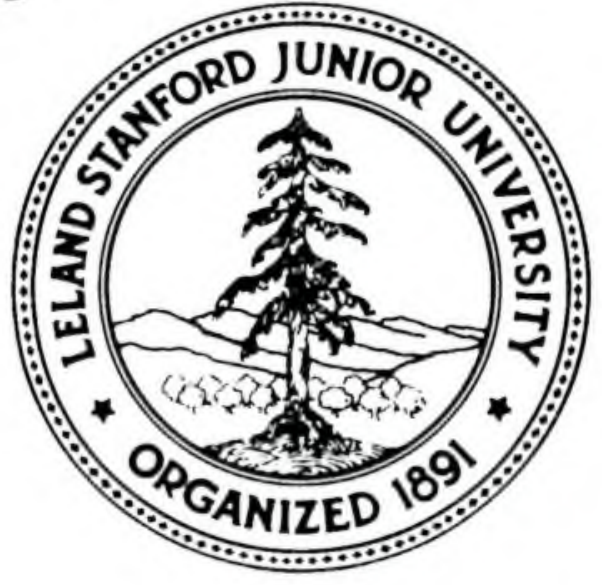
Stanford
University 
filled; review will begin November 15, 1988. Applications will be accepted until the position is filled. AA/EOE. Women and minorities are encouraged to apply

DIRECTOR of the Stitt Library, Austin Presbyterian Theological Seminary. The Librarian is responsible for the overall management of the Library, including collection development, acquisitions, cataloging, public services, circulation, collection management, budgeting, and supervision of library staff (currently 2.5 full time and 10-15 student aides). The Director has responsibility for planning future development of the Library and for further automation of the library functions. The Librarian is accountable to the Academic Dean and the President. He or she participates in faculty meetings and is invited to teach in his/her field of competence. Requirements: MLS from ALA-accredited school and a Master's degree from a school accredited by the Association of Theological Schools. A Ph.D. in a theological discipline is desirable, as is membership in the Presbyterian Church (USA). Deadline: February 1, 1989. The position is available June 1, 1989. Salary $\$ 30,000-\$ 40,000$. Send resume and references to: Jack L. Stotts, President, Austin Presbyterian Theological Seminary, 100 E. 27th Street, Austin, Texas 78705. Austin Presbyterian Theological Seminary is an Affirmative Action, Equal Employment Opportunity Employer.

HEAD OF LEWIS TOWERS LIBRARY, Loyola University of Chicago. New position. Manages daily operations including general reference services and circulation services in the University's Water Tower Campus library. Reference services include desk service, online public catalog support (NOTIS), database searching, library instruction, periodicals information, and end user support. Supervises 4 librarians, 7.5 support staff and students. Also serves as Assistant Head of Public Services. Reports to the Assistant University Librarian for Public Services. Qualifications include: ALA-accredited MLS degree; progressively responsible experience in public services in an academic library; supervisory experience; demonstrated leadership skills; excellent communication and interpersonal skills; knowledge of and interest in the creative use of technology in the delivery of reference services. Salary commensurate with qualifications and experience. Base salary $\$ 27,000$. Librarians have limited faculty status, are eligible for librarian leaves after 3 years, earn 20 days of vacation and have a standard package of fringe benefits including university contributions to TIAA/CREF. Applications received by December 15,1988 , will receive first consideration, but applications will continue to be accepted until the position is filled. Qualified applicants should send letter of application, resume and the names, addresses and phone numbers of three references to: Ellen J. Waite, University Librarian, Cudahy Library, Loyola University of Chicago, $6525 \mathrm{~N}$. Sheridan Road, Chicago, IL 60626. Loyola University is an affirmative action educator and employer

HEAD, SCIENCE AND ENGINEERING LIBRARY. The University of Alabama Libraries, Tuscaloosa, invite applications for the position of Head of the Science and Engineering Library (SEL), a new 80,000 square feet branch library to be completed in two phases, the first scheduled for completion in December 1989. The library, equipped with current information handling technologies, will feature an electronic classroom to be used as a research center for the development of information delivery services by researchers in the Sciences, Engineering, Computer Science, the Graduate School of Library Science, and SEL library staff. The Head of SEL will administer the new branch library, including planning for and implementing merger of the current Science Library and the current Engineering Library. The merged library will result in an SEL staff of three librarians, four classified staff and 9,000 hours of student assistance. The Head of SEL will be responsible for: collection development; reference services; circulation; reserve; binding; automated search services; library instruction including an increasing emphasis on end user search instruction; coordination with main library technical services departments; planning, maintenance, analysis and evaluation of services; the implementation of new modes of services for evaluation purposes; and staff development and evaluation. This position will report to the Associate Dean of Libraries for Collections and Information Services. Required: MLS from a program accredited by ALA: advanced relevant subject degree' or equivalent combination of experience and education in the sciences and/or in engineering; at least three years experience in public services in science or engineering unit of research library; demonstrated supervisory experience, online database search experience; a record of professional and/or scholarly activity; excellent oral and written communications skills; demonstrated ability to work productively with researchers, faculty, students, and library personnel at all levels, and a commitment to client-centered services. Preferred: Demonstrated knowledge of academic processes, experience in staff development and in collection development. Twelve month, faculty rank, tenure earning, excellent benefits package. Salary and rank depend on qualifications. Minimum salary: $\$ 28,000$. Send cover letter, resume, and names and address of three references to: Sondra Tucker, Personnel Officer, SEL Search Committee, The University of Alabama Libraries, P.O. Box 870266, Tuscaloosa, Alabama 35487-0266, by November 21, 1988. The University of Alabama is an equal opportunity, affirmative action employer.

HEAD, SERIALS UNIT. Bibliographic Records Services Department, The University of Virginia. Reporting to the Director of Bibliographic Services, the Head of the Serials Unit manages, organizes, and coordinates the work of 1 faculty member, 7 support staff and some parttime student employees responsible for precatalog search and cataloging of serial titles; retrospective conversion of previously cataloged serial records; and update of serial records. Hires, trains, evaluates staff; establishes and monitors workflow, maintains consistency and uniform application of policies, and develops operational procedures. Works with department head and other unit heads to

\section{The SUNY College of Technol- ogy at Utica/Rome is extending its search for a SENIOR/ASSISTANT LBRARIAN}

to serve as the college's senior public service librarian.

RESPONSIBILITIES include: overseeing bibliographic instruction, reference services, on-line computer searching, CD-ROM, inter-library loans, and automated circulation. The college is an upper division and graduate college. The library is a full QCLC user and supports a new LS 2000 integrated library system.

QUALIFICATIONS: M.L.S. required; experience in academic library reference and automated services preferred; subject knowledge in business and technologies, including engineering or health sciences desired.

Salary: $\quad \$ 21,000-\$ 28,000$, with excellent benefit package.

Submit letter of application and resume by November 30, 1988 to:

\section{Mr. Anthony F. Panebianco} Director of Personnel/Affirmative Action

\section{SUNY College of Technology at Utica/Rome}

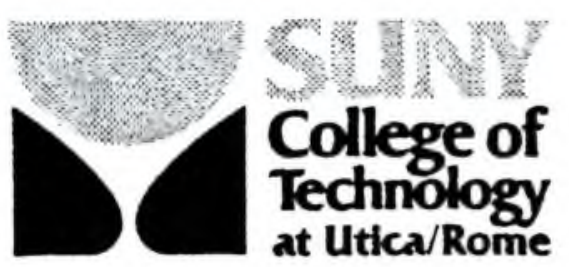

Drawer 8012, P.O. Box 3050 Utica, New York 13504-3050

An Equal Opportunity/Affirmative Action Employer 
establish priorities, allocate personnel and resources, and make long-range plans. Assists in the preparation for the transition to an online catalog. Required qualifications: ALA-accredited MLS; experience in serials cataloging and control preferably in a research library, knowledge of the Anglo-American Cataloging Rules, 2nd ed., LC classification and subject headings, MARC formats, and an automated cataloging system such as OCLC; skills in organizational leadership or supervision, communication, and human relations, ability to work harmoniously with many levels of staff in a rapidly changing environment. Preferred qualifications: Ability to write procedures and create appropriate documentation; working knowledge of one or more Western European languages; familiarity with national trends in serials control and library computer applications demonstrated commitment to professional growth. Salary: $\$ 25,000$ or higher, depending upon qualifications. General faculty status, 22 days vacation, generous sick leave, Blue Cross/Blue Shield, state and TIAA/CREF retirement plans, research leave. Applications received before December 5, 1988, will be given first consideration. Send letter of application, resume, and names, addresses, and phone numbers of three references to: Gail Oltmanns, Personnel Director, Alderman Library, University of Virginia, Charlottesville VA 22903-2498. An Equal Opportunity, Affirmative Action employer.

HISTORY AND GEOGRAPHY BIBLIOGRAPHER (search reopened). Division: Collection Management. Reports to: Assistant University Librarian for Collection Management. The library: Northwestern University Library has a collection of about 2.5 million volumes (excluding the Dental, Medical, and Law Libraries). The collections are highly centralized in two major buildings. The Library has a so phisticated online database (NOTIS) for both technical processes and patron access. The selection of library material is managed by several subject specialists' working throughout the Library. Position Summary: The History and Geography Bibliographer selects material to support instruction and research in history and geography The Bibliographer cultivates strong working relations with the cooperation with other selectors, with the Conservation Officer, and with the Reference, Acquisitions, Serials, and Catalog departments. Specialized bibliographic instruction or other teaching is another major responsibility. The Bibliographer is responsible for collection evaluation and weeding in his or her areas of selection and for acquisition fund management. Qualifications: Advanced degree in history required; Ph.D. highly desired. Master's degree from an ALAaccredited library school highly desired. Strong reading knowledge of at least two modern European languages; commitment to bibliographic instruction or research, preferably to both; effective communication skills. Previous selection responsibility for history materials in a research library preferred. Salary: $\$ 10,500-\$ 14,500$ (for .5 FTE) depending on experience and qualifications. Send letter of application and resume, including names of three references, to: Debra Domanico, Personnel Manager, Northwestern University Library Evanston, IL 60208. EEO/AA.

HUMANITIES/SOCIAL SCIENCES LIBRARIAN. Provides general as well as in-depth humanities or social sciences reference service, including online literature searching; selects library materials in designated subject areas, teaches library usage and serves as liaison with one or more academic departments. Qualifications: MLS from an ALA-accredited library school; degree in social sciences or humanities preferred; reading knowledge of at least one foreign language desirable; knowledge of online searching, preferably BRS or Dialog; experience in reference or collection development in an academic library desirable. Minimum salary $\$ 19,728$. Send letter of ap-

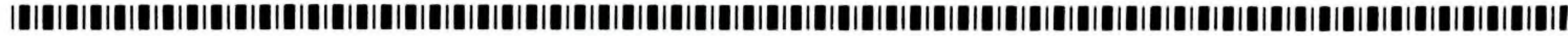

\section{Ball State ASSISTANT DEAN FOR University LIBRARY PUBLIC SERVICES}

As a member of senior library management working directly with the Dean of University Libraries, the Assistant Dean for Library Public Services provides ongoing leadership for a strong program of public services. The University Libraries consist of a main collection and two branch libraries. Collections total 1.4 million volumes and a large, active media collection. The University Libraries are in the process of implementing an automated system.

The incumbent is responsible for: administering the daily operations of Library Public Services with a staff of 23 librarians and 39 staff members; allocating budgetary and personnel resources in public service areas; planning, implementing, and evaluating public services and general library policies and programs; coordinating public service activities with other library services; insuring appropriate communications within public service units and with extramural agencies; serving as principal public relations officer

Minimum Qualifications: MLS from ALA-accredited program or equivalent; at least five years increasingly responsible professional library experience in an academic library (including significant experience at administrative levels); demonstrated skills in planning, leadership, communication and interpersonal skills. Preferred Qualifications: Additional earned degree(s), experience implementing library automated systems, evidence of strong commitment to library services through a personal record of educational, scholarly, and professional achievement which merits appointment at senior faculty rank. Twelve month appointment with excellent fringe benefits. Salary negotiable: $\$ 42,000$ minimum. Possible tenure track appointment with faculty rank and status at senior rank, depending on credentials.

Send letter of application, resume, graduate degree(s), transcripts (unofficial copies acceptable), and list of four references including addresses and telephone numbers to:

\section{William Barnett \\ Business Manager, University Libraries \\ Bracken Library Room 101 \\ Ball State University \\ Muncie, IN 47306}

Review of applications will begin immediately and will continue until the position is filled.

Ball State University Practices Equal Opportunity in Education and Employment. 
plication, resume and three letters of reference to: Personnel Office, Box 1184, Washington University, One Brookings Drive, St. Louis, MO 63130. Applications accepted until November 30, 1988 , or until position is filled. Employment eligibility verification required upon hire. Washington University is an equal opportunity, affirmative action employer

INTERNATIONAL, FOREIGN AND COMPARATIVE LAW LIBRARIAN. The International Law Librarian will direct the operations of the international Law Department; provide detailed and thorough reference service in foreign and international law to faculty, students, alumni, law firms, and other library users; lecture on international, foreign and comparative law and United Nations materials to Columbia graduate students and other groups; manage the United Nations depository collection; participate in cooperative collection development projects of RLG law libraries. An accredited MLS and either: 1) an ABA-accredited JD and extensive knowledge of the civil law system, or 2) law degree from a recognized law school of a civil law country and extensive knowledge of the American legal system are required. Previous relevant work experience with international legal materials can be substituted for one of the required degrees. Additional requirements are: working knowledge of two or more foreign languages, one of which must be western European (German preferred); knowledge of foreign and international legal bibliography; excellent written and verbal communication skills; and the ability to work effectively with the public. Previous administrative/supervisory experience is preferred. Salary commensurate with qualifications and experience (minimum $\$ 30,000$ ). Excellent benefits, including tuition exemption for self and family and assistance with University housing. Send resume, listing three references, to: Kathleen Wiltshire, Director of Personnel, Columbia University, Box 35 Butler Library, 535 West 114th Street, New York, NY 10027. Deadline for applications is November 30, 1988. An Affirmative action, equal opportunity employer.

LIBRARIAN FOR SPECIAL PROGRAMS. This an administrative staff position reporting to the University Librarian. The individual in this position exercises broad administrative responsibility in a number of diverse areas. These are: working with proposers of new programs and courses to identify library resource needs; support for offcampus locations including programs offered through the Asheville Graduate Center; support for non-credit summer programs; liaison with community colleges, high schools and the North Carolina Center for the Advancement of Teaching; preparing, coordinating and editing library publications; planning and implementing a staff devel- opment program. The person in this position will also work at the reference desk a few hours a week and serve as a subject bibliographer. Required: Master's degree in Library Science from an ALA-accredited library school, at least six years professional experience in a library. Candidate must demonstrate an understanding of the instructional and research needs of students and faculty, give evidence of well-developed planning and organizational skills, possess good oral and written communication skills and an ability to work effectively with library staff and the University community. Preferred: Evidence of successful library program or project design and implementation. Experience with staff development. Experience with automated systems. Position is twelve month, tenure track, choice of TIAA/CREF or state retirement system. Salary $\$ 29,000 \sim \$ 34,824$ depending upon experience. Send letter of application, resume, transcripts and names and telephone numbers of three references to: William J. Kirwan, Chairman, Search Committee, Hunter Library, Western Carolina University, Cullowhee, NC 28723. Preference will be given to applications received by December 15, 1988. Hunter Library has an operating budget of 1.9 million and a staff of 40 , including 13 professional librarians. It serves a student body of approximately 6,000 enrolled in programs through the Master's level. Some these programs are offered in Asheville with support provided in cooperation with the library at the University of North Carolina at Asheville. Western Carolina University, with two other state universities, has formed the Western North Carolina Library Network, which shares a LS/2000 online catalog/circulation system. Western Carolina University is one of the sixteen senior institutions of the University of North Carolina and an affirmative action, equal opportunity employer. The University is located between the Great Smoky Mountains and the Blue Ridge Mountains, 55 miles west of Asheville, North Carolina.

LIBRARY CATALOGER (Search Reopened). The University of Ak ron is seeking an entry level, non tenure-track cataloger. Responsibilities: catalog and classify new library collection materials in all formats using LC classification and practices, LCSH, OCLC and a local online system; catalog and/or classify two special collections-government documents and curriculum center materials; perform cataloging authority work using the online files or creating original records; and create MARC coded holdings records in conjunction with serials cataloging. Requirements: ALA-accredited MLS; knowledge of MARC formats, AACR2, LC classification, LCSH and automated systems. Preference will be given to candidates with experience in an academic setting, with automated systems, and a demonstrated interest in cataloging. This position carries a 12-month

\title{
ASSISTANT DIRECTOR OF LIBRARY FOR TECHNICAL SERVICES AND AUTOMATION Bloomsburg University of Pennsylvania
}

Responsible for coordination of cataloging, processing and library automation (including implementation of PALS) and for library operations during academic intersessions.

Requirements: ALA-accredited MLS, 4 years experience in technical services or library systems, preferably in academic/research libraries, management experience demonstrating strong management skills, demonstrated abilities in oral and written communication, broad knowledge of academic library automation. Preferred: Additional Master's in related field.

Starting date: Preferably by July 1989. Rank: Manager 4. Anticipated starting salary range: $\$ 28,238-\$ 36,000$. Liberal fringe benefits. Send application, curriculum vitae, and names and addresses of three references by December 17, 1988, to:

\author{
Marilou W. Zeller \\ Chairperson, Search and Screen Committee \\ Harvey A. Andruss Library \\ Bloomsburg University \\ Bloomsburg, PA 17815
}


contract and 22 days of vacation with standard benefits package. Salary: $\$ 16,000-\$ 18,000$. To apply send letter of application with resume and three reference by December 15, 1988, to: Judith L. Fitzgerald, Chair, Cataloger Search Committee, Bierce Library, The University of Akron, Akron, $\mathrm{OH} 44325$. The University of Akron is an Equal Education and Employment Institution.

MANAGER OF LIBRARY PERSONNEL. Responsible for recruitment, compensation, staff development, performance review, salary administration, employee relations, and records management for the Northwestern University Library. Qualifications: BA degree and training and experience in personnel management required. Knowl edge of and/or experience with personnel issues/programs related to academic school librarianship; accredited MLS preferred. Demonstrated supervisory, communication, and leadership skills essential. Salary: low to mid $\$ 20$ 's. Send letter of application and resume, including the names of 3 references, to: Jacqueline Gibbs, Manager of Employment, Northwestern University, 720 University Place, Evanston, IL 60208. Position vacant until filled. EEO/AA

MONOGRAPHS LIBRARIAN. Sam Houston State University Library. Reporting to the Head of Technical Services, the appointee will be responsible for cataloging of all library monographic materi- als; establishing policies and procedures for the creation and management of the library's bibliographic and machine readable files. Required: ALA-accredited MLS; minimum three years experience in a cataloging unit in an academic library; knowledge of OCLC, LCSH, AACR2, and MARC tagging and formats; experience with an online integrated system desirable; good interpersonal and communications skills. Nine month tenure-track position with second master's required for tenure. Salary $\$ 19,000$ minimum depending upon qualifications and experience. Send letter of application, resume, and the names, addresses, and telephone numbers of three references to: David Kim, Head, Technical Services and Assistant Director, Newton Gresham Library, Sam Houston State University, Huntsville, TX 77341, by November 30, 1988. SHSU is an Affirmative Action, Equal Employment Opportunity employer.

PHYSICAL SCIENCES REFERENCE LIBRARIAN/BIBLIOGRAPHER. Responsible for the Library's collection development in assigned physical science disciplines. Provides service at information desk, including some weekend and evening hours. Participates in an active program of library instruction and computerized database searching in the disciplines of selection responsibility. Requires an ALA-accredited Master's degree and significant coursework in physical sciences or significant science reference experience. Ex-

\title{
ASSISTANT DIRECTOR FOR PRESERVATION, RESOURCES GROUP
}

\section{Columbia University}

Reporting to the Resources Group Director, the Assistant Director for Preservation directs and oversees Columbia's preservation program, and participates in setting system-wide priorities and policies. The incumbent will promote the implementation of conservationally sound preservation standards and procedures; share responsibility for initiating and preparing large grant applications and overseeing grant implementation; monitor performance of outside microfilming and binding vendors; cultivate an understanding of preservation concerns throughout the library community; and represent the preservation program at state, regional and national forums.

The Columbia University Libraries' preservation program was organized in 1974 as one of the first in the United States. Administratively it includes the Assistant Director, one professional librarian, a conservator, a paralibrarian and 21 FTE support staff members organized into four departments: Materials Processing, Conservation Laboratory, Preservation Records Office, and Reprographic Laboratory. Annually over 5,000 volumes are microfilmed; 50,000 volumes bound or rebound; 3,500 treated in the conservation laboratory; and 60,000 items are shelf processed. In addition to University funds, the program is supported by grants from Mellon, NEH, New York State, and others.

In addition to an accredited MLS, requirements include advanced library preservation or conservation training; at least three years of successful preservation related experience; evidence of leadership, planning, communication and management skills; ability to direct others and adapt to new technologies; and familiarity with the problems of large academic institutions.

Salary ranges are: Librarian II: $\$ 32,500-\$ 43,875$; Librarian III: $\$ 35,500-\$ 51,475$; Librarian IV: $\$ 39,500-\$ 55,300$. (Appointment at Librarian IV is for individuals demonstrating exceptional experience and achievement.) Excellent benefits, including assistance with University housing and tuition exemption for self and family.

Send resume, listing three references, to:

\author{
Kathleen Wiltshire \\ Director of Personnel \\ Box 35 Butler Library \\ Columbia University, \\ 535 West 114th Street \\ New York, NY 10027
}

Deadline for applications is November 30, 1988. 


\section{ASSOCIATE DIRECTOR FOR COLLECTION DEVELOPMENT AND MANAGEMENT}

\section{The University of Tennessee, Knoxville}

The University of Tennessee, Knoxville Library invites applications and nominations for the position of Associate Director for Collection Development and Management. Reporting directly to the Dean, the Associate Director is a member of the Library Executive Committee.

Responsibilities: Responsible for development and management of the library's collections in support of the University's teaching and research activities. Formulates and implements collection development policies and procedures. Allocates and controls budget in excess of $\$ 2.5$ million for scholarly information resources in support of university programs. Responsible for policy formulation for providing access to scholarly resources, including print, non-print, and electronic formats. Coordinates selection process with academic faculty. Assesses collection strengths and weaknesses and develops plans to correct inadequacies; prepares statistical reports and budget analyses. Actively participates in planning innovative cooperative programs for coordination and sharing of scholarly resources on a local, regional, and national scale; represents the UTK Library in regional and national networks. Coordinates work throughout the library on matters relating to the collections. The successful candidate will have an understanding of and demonstrated commitment to equal employment opportunity and affirmative action.

Qualifications: Required: Substantial collection development or related experience, preferably for a minimum of 5 years in a major research library; excellent writing, speaking, and interpersonal skills; knowledge of national and international trends and issues in research libraries; knowledge of the book, publishing, and online information trades; demonstrated analytical skills, creativity, and innovation; demonstrated ability to work effectively with faculty and staff and to coordinate activities in a number of areas simultaneously; demonstrated managerial skills and leadership abilities. The successful candidate must have knowledge and understanding of the information needs of students and faculty in a research university and of the role of the library in meeting those needs. Preferred: ALA-accredited MLS degree, additional graduate degree(s), foreign language competency, fund-raising experience. Library faculty must meet university requirements for promotion and tenure.

The University of Tennessee is a multi-campus system of higher education and the state's official university and federal land-grant institution. UT, Knoxville is the major comprehensive university in the four campus system. The UTK Library, with an annual budget in excess of $\$ 6.2$ million, holds 1.5 million volumes and receives over 18,000 current serials. The new Central Library facility opened in September 1987. A major Library Development Campaign is now underway. The library is a member of SOLINET, the Association of Research Libraries and the Center for Research Libraries.

Librarians at the University of Tennessee, Knoxville have faculty rank and status and are appointed for twelve months. This is a tenure track appointment. Tuition remission is available to university employees; partial undergraduate tuition remission is available to dependent children and spouses of UT employees. There is no state income tax.

Salary: $\$ 50,000$ minimum.

Send letter of application, a current resume, and the names, addresses and telephone numbers of three recent references to:

\section{Jill Keally \\ Personnel Librarian \\ The University of Tennessee Library \\ Knoxville, TN 37996-1000}

Review of applications will begin January 15, 1989, and will continue until the position is filled. The position is available April 1989. 
$\$ 32,472$ or Associate Librarian: $\$ 31,008$ to $\$ 44,676$. Start date of April 17, 1989. Two positions are available. Under the general guidance of the Head of the Undergraduate Library, the successful candidate provides reference service at the reference desk 13 to 16 hours per week plus some weekends; conducts online literature searches where appropriate; and prepares various reader aids such as pathfinders, subject bibliographies, orientation leaflets, and guides to the use of the library and its resources. The successful candidate also serves; as an instructor for a two-unit library research course at least one quarter per year, and participates in library instruction presentations, orientation programs, and tours. The person filling this position may atso serve as coordinator for reference, instruction, collection development, or a proposed instructional mircrocomputing center. Collection development assignments will be made, insofar as are possible, according to the successful candidate's strengths. A strong background in the sciences is preferred but not required. The person filling this position will participate in librarywide committees and other professional activities, and will perform other duties as assigned. Qualifications: Required: MLS from an ALA-accredited library school and strong oral and written communication skills. Highly desired: reference experience in an academic library, classroom instruction ability, and general knowledge of microcomputer technology and software. Desired: academic major in the physical or life sciences. An appointee at the Associate level would be expected to bring to the position substantial relevant experience, including instruction, collection development, and computerassisted literature searching. UCSD is an equal opportunity, affirmative action employer. Applications received by January 13, 1989, will be assured of consideration. Submit a letter of application, enclosing a resume and a list of references to: Ellen Lawson, Assistant for Academic Personnel, Library, C-075- $\mathrm{H} 1$, University of California, San Diego, La Jolla, CA 92093-0047.

SCIENCE/ENGINEERING LIBRARIAN. One of a team of librarians serving the reference, computer searching, bibliographic instruction, and collection development needs of the users of the Centennial Science and Engineering Library. Serves as library liaison to assigned Science/Engineering Department(s). Required: Master's degree from ALA-accredited program, strong commitment to and ability for public services. Preferred: An undergraduate major or graduate degree in science or engineering or work experience in a science or engineering library. Mathematics or engineering sciences background is desirable. Must comply with policies of Faculty Handbook including research, publication and service to the profession and community. Minimum salary, $\$ 20,000$. Submit resume including the names and addresses of three references by November 18, 1988, to: Rita Critchfield, General Library, Personnel Office, University of New Mexico, Albuquerque, NM 87131. Recruitment will continue until position is filled. AA/EOE.

SCIENCE/SERIALS LIBRARIAN. Le Moyne College seeks a librarian to share, with four other professionals, the operations of public and technical services. Responsibilities: Provide general reference service and bibliographic instruction, provide specialized reference services for faculty and students in assigned departments, oversee development of collections and provide bibliographic instruction in assigned subject areas, oversee the operations of serials and interlibrary loan department. Requirements: ALA MLS, an undergraduate

\section{BIBLIOGRAPHER FOR FOREIGN AND INTERNATIONAL LAW Harvard Law School}

Duties: Selects materials for, and oversees the development of, the foreign and international law collections of the Harvard Law School Library, with emphasis upon the jurisdictions of Western Europe and Latin America. Provides reference assistance to the users of the foreign and international collections. Chairs the Foreign and International Selection Committee, which selects serials and other expensive items in foreign and international law. Analyzes collection strengths and makes recommendations for programmatic change. Works with the Acquisitions and Serials Librarians on problems relating to the ordering and receipt of materials; monitors endowment and general income book funds. Reports to the Assistant Librarian for Collection Development.

The Harvard Law School Library serves an international research community as well as the faculty and students of the School. Its collections of 1.5 million volumes from most of the world's legal jurisdictions include more than 12,000 active serial titles. The current book budget is $\$ 1.2$ million. The Harvard Law Library is a member of the Research Libraries Group and the New England Law Consortium. The Harvard On-Line Library Information System is used for integrated technical processing and for the public catalog.

Requirements: Knowledge of foreign and international legal materials; strong bibliographical skills; reading knowledge of German and either French or Spanish and the ability to work with a wide range of languages; excellent English-language written and oral communication skills. Preferential consideration will be given to candidates with an ALA-approved degree in library science, or a degree form an institution certified to provide instruction in the civil law or comparative legal studies. Relevant experience in a research library is also preferred. Appointment at Librarian II rank. Salary negotiable depending upon experience; minimum salary: $\$ 35,000$; generous benefits, including professional development support. For full consideration, send letter, resume, and names of three references by December 31, 1988, to:

\section{Harry S. Martin III \\ Librarian, Harvard Law School Langdeil Hall Cambridge, MA 02138}

Position available July 1, 1989. 


\title{
HEAD, SCIENCE AND
ENGINEERING LIBRARY
}

Position \#116-A, Position Extended. The University of Southern California is seeking a Librarian as Head of Science and Engineering Library. Reports to AUL for Public Services. Manages Science and Engineering Library. Overall managerial responsibilities for Hancock Library of Biology and Oceanography. Science and Engineering library houses primary collection of science, engineering, and neural informational behavioral sciences materials. Responsible for 5 librarians, 9 staff, and student assistants. Supervises collection development, reference, circulation, bibliographic instruction, and database searching. Maintains close liaison with faculty departments. Participates in University library committees, and task forces.

ALA-accredited MLS; second Master's in life sciences, engineering or biomedical disciplines; Undergraduate degree in one science. Minimum 5 years professional library experience, 2 years public services, preferably in academic scientific/medical library. Knowledge of bibliographic control and information sources in science or medicine.

Rank and salary negotiable, depending on experience. Minimum: Librarian II, \$30,495; Librarian III, $\$ 36,166$.

Apply before December 31, 1988. Open immediately, will remain open until filled. Submit letter of application, resume, and names and addresses of three references to:

\section{Carolyn J. Henderson \\ Associate University Librarian for Administrative Services \\ Doheny Memorial Library \\ University of Southern California \\ Los Angeles, CA 90089-0182}

Please refer to Position \#116-A/ACRL on all correspondence.

\section{REFERENCE LIBRARIAN/BIBLIOGRAPHIC INSTRUCTION COORDINATOR}

\section{Southern Methodist University}

Plans, implements Bibliographic Instruction program in humanities and social sciences; develops bibliographies, conducts classes and tours; staffs reference desk; assists with online searching and collection development. Required: ALA-accredited MLS, specialization in reference, relevant teaching or training experience.

Salary: $\$ 18,000$. Benefits include group insurance, savings options, tuition waiver, 22 days vacation, 10 university holidays. Available: January 4, 1989. Send resume, references by November 21, 1988, to:

\author{
Thelma Elkins \\ Head of Reference \\ 104 Fondren Library \\ Southern Methodist University \\ Dallas, TX 75275
}


degree in a natural science (Biology, Chemistry or Physics) or comparable experience as a Science Librarian, knowledge of online searching. Preferred: Knowledge of OCLC. Le Moyne College, with an enrollment of 2,000 students, is a liberal arts college in the Jesuit tradition, committed to academic excellence. Twelve month appointment as Librarian I, salary scale: $\$ 18,250-\$ 27,010$. Appointment at higher rank possible. Submit letter of application, resume and names, addresses and phone numbers of three references to: James J. Simonis, Chair, Library Recruitment Committee, Le Moyne College Library, Syracuse, NY 13214. Review of applications to begin on November 28, 1988, and to continue until position is filled. Starting date is January 16, 1989. An AA, EOE Employer.

SOCIAL SCIENCES/REFERENCE LIBRARIAN, Mississippi State University Libraries. Qualifications: B.A. or B.S. degree required, with emphasis on the Social Sciences preferred; MLS degree from ALA-accredited library school required; one or more years reference work experience in an academic library preferred. A broad understanding of the Social Sciences is required. Supervisory and organizational capabilities necessary. Applicant must be interested in and have the ability to communicate effectively with the faculty, staff and students. Duties: Responsibilities include general reference functions, collection development activities, working with periodicals and serials, supervision of student assistants, subject area database searching, participation in bibliographic instruction/tours, committee activities, and other duties as assigned. Benefits: Include faculty rank, status, privileges and responsibilities; enrollment in the State Retirement System; comprehensive medical coverage; University holidays and annual and health care leave. Salary: Approximately $\$ 20,000$, depending upon qualifications and experience. Position Available: This position will be filled only if a suitable applicant is found. The Search and Screening Committee will begin to consider nominations and applications immediately and will continue to do so until the position is filled. Applications Procedure: Send letter of application and resume, including names and addresses of at least three references (preferably work) by December 15, 1988, to: Bette Rice, Chair, Search Committee, P.O. Box 5408, Mississippi State University, Mississippi State, MS 39762. Mississippi State University is an Equal Opportunity, Affirmative Action Institution.

SPECIAL COLLECTIONS LIBRARIAN. The University of Arizona Library is seeking a Special Collections Librarian to provide refer-

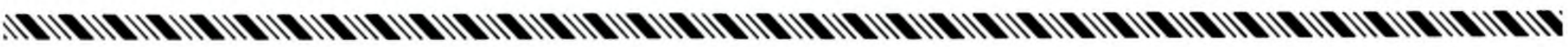

\section{SOCIAL SCIENCES LIBRARIAN}

\section{Trinity University}

Trinity University, San Antonio, Texas, invites applications for the position of Social Sciences Librarian, a faculty appointment. San Antonio, site of the ALA 1988 Midwinter meeting, is the nation's ninth largest city. Trinity, with 2300 undergraduates and 200 graduate students, is strongly committed to excellence in the liberal arts and sciences tradition. Scholarly achievement is recognized through Phi Beta Kappa, other national honor societies, and increased emphasis on undergraduate research. Selective admissions, highly qualified faculty, and outstanding teaching programs place Trinity among the excellent liberal arts and sciences universities in the nation. The Library has undertaken an accelerated program of collection development; presently the collection has more than 600,000 volumes of books and bound periodicals (compared with 300,000 in 1980), plus sizable holdings of government documents, microforms, and nonprint items.

Primary responsibilities of the position involve frequent liaison work between the social science departments and the Library including user education, collection development, and online computer searching, as well as general reference work.

Qualifications include an appreciation for and commitment to undergraduate liberal arts and sciences education, initiative, energy, and creativity; good interpersonal skills; the ability to function effectively in a complex organization; strong professional commitment; interest in research and publishing; and an ALAaccredited MLS. In addition, preference will be given to candidates with an academic background including a graduate degree in an applicable subject area or with relevant library experience, preferably in strong liberal arts and sciences institutions, and to those with considerable interest in and enthusiasm for user education and faculty liaison programs. In short, we seek an academic librarian who wishes to function in a campus community as an academic and a librarian.

Instructor or Assistant Professor rank with faculty status, including tenure-track. Salary minimum $\$ 22,000$, higher depending on experience or other qualifications; twelve-month appointment; TIAA/CREF and other fringe benefits. Send letter of application, detailed resume, placement file if available, and names, addresses and phone numbers of three references to:

\section{Barbara J. Ford \\ Associate Director \\ Maddux Library \\ Trinity University \\ 715 Stadium Drive \\ San Antonio, Texas 78284}

Deadline for applications is January 20, 1989; however, receipt of applications by December 16, 1988, will facilitate interviewing at the ALA Midwinter meeting in Washington, D.C. 
ence assistance and to aid in the selection, acquisition and processing of books, photographs and ephemera. The Special Collections Librarian reports to the Head Special Collections Librarian and is one of three professionals and 2.8 support staff in the department. Re quirements include a Master's degree in Library Science from an ALA-accredited school; excellent oral and written communication skills; ability to work effectively with a wide variety of people; demonstrated initiative. Experience in an academic/research library and a background in cataloging and/or southwestern studies are preferred. Minimum salary: $\$ 20,000$; higher salary is negotiable depend ing upon qualifications and experience. Librarians at the University of Arizona have academic professional status, are eligible for continuing status, are voting members of the faculty, and may take up to 24 days professional leave per year. They have 22 days paid vacation, 12 days sick leave and 10 holidays. Send a letter of application, re sume and names of three references to: $W$. David Laird, University Librarian, P.O. Box C, University of Arizona Library, Tucson, AZ 85721 , by December 15,1988 . The position will be available March 6,1989 . The University of Arizona is an Equal Employment Opportunity Employer with an Affirmative Action plan. Women and minorities are urged to apply. In compliance with the Immigration Reform and Control Act of 1986, all persons hired after November 6, 1986, will be required to show proof of their identity and right to work in the United States

UNIVERSITY ARCHIVIST with Faculty Rank and Tenure Track. A newly-created position reporting directly to the University Librarian. Establish, organize, and administer the University Archives and other collections of historical material relating to OSU. Develop close working relationships with faculty, administration and staff; recommend policies and procedures for the operation of University Archives; provide service to users; supervise part-time staff; plan for the future development of the archival collections. MLS from ALA accredited graduate program with archival concentration preferred or graduate degree in history or archival management; two years professional experience in archival work preferably with university archives. Desirable qualifications: some supervisory experience; knowledge of microcomputer applications to archival materials processing; additional graduate study; a record of professional involvement. Good fringe benefits. Salary: $\$ 25,000-\$ 28,800$, for 12 months. Salary and rank dependent upon qualifications and experience. For full consideration, applications should be received by January 1,1989; applications will continue to be considered until position is filled. Send letter, resume, and names of three references to: Edward R. Johnson, University Librarian, Oklahoma State University, Stillwater, OK 74078-0375. AA/EO Employer. Successful applicant must comply with IRCA

UNIVERSITY LIBRARIAN. The University of Adelaide, South Aus tralia, invites applications from both women and men for appointment as University Librarian (Ref: 1842) in the Barr Smith Library. The University Librarian will be responsible for the provision of an effective library and information service to the University community, formulation and implementation of Library policy in consultation with the University Library Committee, and for representing the University in cooperative library initiatives at the local, State and Nationa level. The Barr Smith Library has a staff of 125 , has more than $1,300,000$ volumes, operates on an annual budget in excess of $\$ 6$ million and serves some 9,000 students and 700 academic staff. For further information about the Barr Smith Library please ring Jim Anderson, Telephone (08) 228-5223. Qualifications and experience: Applicants should possess a tertiary degree and recognized professional qualifications in librarianship, together with substantial experience at a senior level in a research or academic library. The successful applicant will be able to manage change, and apply modern information technology in delivering library services, and will have contributed to professional librarianship. In addition, there will be evidence of good interpersonal skills and the capacity to provide strong intellectual leadership. Salary: Salary will not be less than $A \$ 60,000$ per annum. Information about terms and conditions of employment for all positions may be obtained from the Senior Assistant Registrar (Personnel). Applications, in duplicate, quoting reference number 1842 and giving full personal particulars (including whether candidates hold Australian permanent residency status), details of educational qualifications, current salary and names and addresses of three references should reach: The Senior Assistant Registrar (Personnel), Personnel Services Branch, The Registry, University of Adelaide, GPO Box 498, Adelaide,SA 5001, no later than 16 December 1988 . The University reserves the right not to make an offer of employment and to make inquiries of any person regarding any applicant's suitability for employment. The University of Adelaide is an equal opportunity employer.

\section{Immediate Opening SCIENCE LIBRARIAN}

Franklin and Marshall College is currently constructing a Science Library which is scheduled for completion in January 1990. The new facility will consolidate four branch libraries (biology, chemistry, geology, \& physics) and also support the library programs in astronomy, computer science, the history of science, mathematics, and psychology (total 55,000 volumes, 540 current journal subscriptions).

We have an immediate opening for a librarian to help plan the interior spaces, to direct the move, and to head the library upon completion. Other duties include bibliographic liaison with science departments, bibliographic instruction, online searching, and participation in the implementation of Data Research Associates' ATLAS software. The Science Librarian will report to the Library Director. This is an excellent opportunity to inaugurate a state-of-the-art science library into a scientific community known for excellence in undergraduate research.

Qualifications: ALA-accredited MLS; undergraduate degree in a natural science or equivalent combination of education and experience in a science library; at least 3 years' experience in an academic or special library; knowledge of microcomputing, library automation and online database searching. A graduate degree in a natural science and experience in bibliographic instruction are highly desirable.

Send letter of application, resume, and names, addresses and telephone numbers of at least three professional references to: Elizabeth Stegner, Director of Personnel Services, Franklin \& Marshall College, P.O. Box 3003, Lancaster, PA 17604-3003. Consideration for the position will begin November 20,1988, and will continue until an appointment has been made.

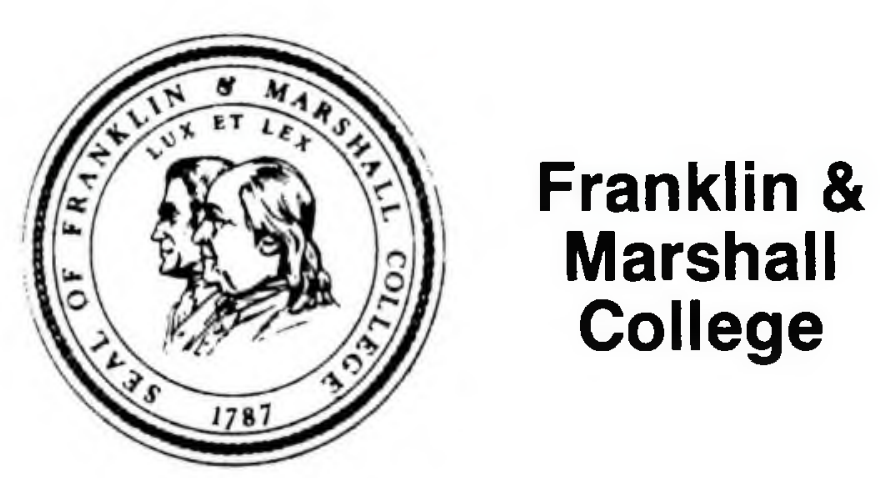

An Equal Opportunity Employer 
BUSINESS REFERENCE LIBRARIAN, University of North Texas, Denton. Position Description: The Business Reference Librarian provides reference service to the students, faculty, and other patrons of the collection in the University Libraries primarily in the fields of Management, Accounting, Marketing, Finance, Insurance, Business Law, and Business Computer Information Systems under the direct supervision of the Head of General Reference Services. This position will have primary responsibility for providing collection development in enhancing the collection, bibliographic instruction and database searching in the assigned areas of business. Minimum Qualifications: A position requiring at least five years of professional experience in business reference in an academic or research library; MLS from an ALA-accredited library school; and an undergraduate subject specialty in business or the social sciences. Preference will be given to individuals with advanced degrees. Knowledge of database searching techniques and teaching experience is also required. Desirable Qualifications: Knowledge of collection development techniques and resources in the field of business. Familiarity of basic computer applications in libraries. The University: The University of North Texas has over 24,000 students and one of the largest colleges of business administration in the United States. The College of Business Administration has over 5,600 undergraduates, 150 doctoral candidates, 730 masters candidates, and 110 faculty members. Available: 1 January 1989. Salary: $\$ 35,000+$. Applicants should send a resume, copies of all transcripts and the names and addresses of three references before December 9, 1988, to: Margaret E. Galloway, Associate Director of Libraries, University of North Texas Libraries, Box 5188 N.T. Station, Denton, TX 76203-5188. University of North Texas is an Equal Opportunity, Affirmative Action Employer.

CATALOGER, SPECIALIZED COLLECTIONS. Performs original and complex copy cataloging of monographs and manuscripts, in a variety of languages, for the libraries specialized and general collections using OCLC, AACR2, LCSH and LC classification. Required: ALA-accredited MLS; knowledge of AACR1 \& 2, LCSH, LC classification, and MARC formats; familiarity with a bibliographic utility such as OCLC. Reports to Chair, Cataloging Department. Preferred: cataloging experience in an academic library; working knowledge of a western European language; experience in writing procedures and documentation; good communications skills. Salary: $\$ 19,500$ minimum for a 12 month appointment. Librarians at KSU have academic rank and are eligible for tenure, sabbatical leave and research support. Vacation of 22 working days. Choice of retirement and medical plans. Kansas State University is a land-grant institution with an enrollment of over 19,000 students and a materials budget of over 2 million dollars. The Cataloging Department, comprised of 19 staff members, catalogs approximately 25,000 titles annually. KSU is located in Manhattan, a community of 45,000 in the rolling Flint Hills. Deadline for application is December 15, 1988. The position will be available after November 17, 1988. Send letter of application, resume, and names, addresses and phone numbers of 3 references to: Charlene Grass, Associate Dean, Kansas State University Libraries, Manhattan, KS 66506. KSU is an Equal Opportunity, Affirmative Action Employer. Women and Minorities are encouraged to apply.

COLLECTION DEVELOPMENT LIBRARIAN, Full-time probationary tenure-track assistant/associate professor to provide leadership in collection development and maintenance activities. Develop and implement collection development and evaluation strategies; work with librarians and instructional faculty to oversee collection development; write collection evaluation reports as required. This public service position, reporting to the Dean, may have other 
duties assigned depending on the skills and background of the incumbent. ALA-approved Master's, subject Master's and three years experience in a compatible library (preferably in collection development) required. Leadership and good communication skills essential. Preference will be given to those who demonstrate collection development experience, online systems experience and who possess other transferable library skills. Salary to $\$ 35,000$ for 180 days per year. Applications from minorities are encouraged. Memorial Library is home to MSUS/PALS, an integrated online library system containing over 1.5 million records, now serving 31 public and private academic libraries in Minnesota and North Dakota. Applications must be postmarked by December 1, 1988. Appointment will be made in early 1989. Apply to: Thomas M. Peischl, Dean of the Library, Mankato State University, MSU Box 19, Mankato, MN 56002.

DIRECTOR OF LIBRARIES. The University of South Carolina invites applications and nominations for Director of Libraries. USC-Columbia has an enrollment of 25,000 students, 1,200 faculty, and grants doctoral degrees in over 62 subject fields. The campus is situated in the center of Columbia, the state capital, which has a metropolitan population of over 400,000 and is one of the fastest growing areas in the Southeast. The library collections are housed in the Thomas Cooper Library which opened in 1976. This building of award winning design contains 7 floors of 289,000 square feet. Three small departmental libraries in business, math, and music are housed separately but are part of the library collections. Collections total more than 2,000,000 volumes, 2,000,000 microforms, and 10,000 periodical subscriptions. The library staff consists of 42 librarians and 87 full-time support staff. Librarians have faculty status and are included in the USC Faculty Tenure System. The current annual operating budget is $\$ 5,500,000$. The library is a member of the Association of Research Libraries, the Center for Research Libraries, the Association of Southeastern Research Libraries, and SOLINET. The NOTIS online system is to be installed during 1988--89. The Director of Libraries reports to the USC System Vice-President for Libraries and Collections. The Director of Libraries is responsible for library planning, budgeting, personnel recruitment and retention, and management of library services on the USCColumbia campus. The Director represents the University at state, regional, and national library organizations, provides leadership of the Library faculty, participates in fundraising, and fosters state, regional and national cooperative efforts. Candidates should have a minimum of an accredited MLS degree and a second master's degree; a doctorate is desirable. A minimum of 10 years library experience, including significant experience as a practicing librarian in a nonadministrative capacity and at least 5 years successful administrative experience with increasing responsibilities in an academic or research library are required. Broad knowledge of budgeting and planning, collection development, information technologies and automated library systems is necessary, as well as commitment to contemporary management principles, academic excellence, and a strong service orientation. Candidates must have demonstrated skills in communication as well as the ability to work collegially with University officers, faculty, staff, students and the public. Experience with library building expansion is desirable. Salary is commensurate with qualifications, with a minimum of $\$ 65,000$. Applications and nominations should be sent to: The Chair of the Search Committee, Fred W. Roper, College of Library and Information Science, University of South Carolina, Columbia, SC 29208. Applicants should send a resume, the names, addresses and phone numbers of 3 professional references, and a statement of professional objectives and philosophy of academic library service and management. Review of applications will begin on December 1, 1988, and will continue until the position is filled. The University of South Carolina is an Affirmative Action, Equal Employment Opportunity Employer. Minorities and women are encouraged to apply for this position. 
ENGINEERING LIBRARIAN: The Engineering Librarian is responsible for supervision of the engineering branch library and reports to the Director of Libraries. Duties include supervision of staff, the provision of reference services, including online database searching; the provision of orientation and bibliographic instruction; liaison between the Engineering College and the Main MSU Libraries for selection of material; the circulation, evaluation, and weeding of the Engineering Library material. Qualifications: Required: MLS from ALA-accredited program; strong interpersonal skills; excellent communication skills; strong service orientation. Preferred: Record of published scholarship; minimum of 3 years, post MLS experience; familiarity with bibliographic control and subject literature of engineering. Engineering/science degree/background, or experience in Engineering library; additional subject graduate degree. MSU Libraries: The libraries of Memphis State University contain in excess of 1 million bound volumes and more than 2.5 million pieces of micromaterial. Collections and services are supported by an online catalog of $450 \mathrm{~K}+$ records and an automated circulation system. The Libraries also provide a full complement of online search services. Terms of Appointment: Appointment will be tenure-track with faculty rank. Benefits include 24 days annual leave per year; 12 days sick leave per year; paid state retirement or TIAA/CREF; group health insurance available. Salary minimum is $\$ 26,500$. Review of applications will begin October 15 and will continue until position is filled. Send application, including resume and names, addresses, and telephone numbers of 4 references, to: Lester J. Pourciau, Director of Libraries, Memphis State University, Memphis, TN 38152. Memphis State University is an Equal Opportunity, Affirmative Action University. The University complies with the Immigration Reform and Control Act of 1986 regulation, and proof of employment eligibility is required.

HEAD, ACQUISITIONS DEPARTMENT. Emory University Libraries. Position reports to Director of Technical Services. Plan, organize and direct work of department; coordinate work with other Technical Services Departments and library divisions, particularly Collection Management Division; oversee firm orders, serial subscriptions, continuations, out-of-print orders, form orders for approval plans, and payment of invoices and accounting for funds; maintain working relationship with vendors and University's Accounts Payable Office; responsible for operation of current automated acquisitions system and work with key personnel to implement acquisitions subsystem of DOBIS integrated system for General Libraries. Qualifications: ALA-accredited MLS or equivalent degree; at least 2-3 years of relevant professional experience in an academic research library; prior experience as a supervisor or manager; continuing familiarity with the book trade; and professional activities in the field of acquisitions. Strong interpersonal and communications skills; experience with automated systems. Reading knowledge of at least one modern European language; experience with OCLC or RLIN. Beginning Salary and Rank: Dependent upon qualifications and experience; minimum: Librarian II, \$22,500; Librarian III, \$28,500. Comprehensive benefits package. Position available March 1, 1989. Application Procedure: Send letter of application, resume, and the names, addresses and telephone numbers of three references to: Janet T. Paulk, Library Personnel Officer, Robert W. Woodruff Library, Emory University, Atlanta, GA 30322. Review of materials begins November 20, 1988, and continues until appointment is made. Emory University is an Equal Opportunity, Affirmative Action Employer.

HEAD, REFERENCE DEPARTMENT. Duties: Under the general direction of the Director of Library Public Services, the Head of Reference is responsible for the management of the main library reference department and for planning, 
developing, and evaluating programs and policies. The Reference Department, which includes Government Documents, consists of seven librarians, four support staff, and student assistants. The reference librarians' responsibilities include general and subject-oriented reference, database searching, library instruction, and collection development. In providing reference service, the Head of Reference will work with other public services units including Access Services and branch libraries and with technical services units including Collection Development and Current Periodicals. Qualifications: Required: MLS from an ALA-accredited library school; five or more years experience in public services; substantial supervisory experience; ability to work effectively with faculty, students, and library staff; experience in database searching and/or library instruction; effective oral and written communication skills; evidence of research and publication. Desirable: Knowledge of collection development practices and procedures; second master's degree. Deadline for applications: January 3, 1989. Available: March 1, 1988. Salary: $\$ 32,000$ minimum. Benefits: TIAA/CREF; State Retirement System; comprehensive medical protection; 21 days vacation, University holidays; generous sick leave. University Libraries: A member of the Research Libraries Group and ARL, the University Libraries consists of a main library and six branches. The collection contains more than 2.1 million volumes, 16,000 periodical subscriptions, and three outstanding special collections in history of science, western history, and business history. A major expansion of the main library was completed in May 1982, doubling the size of library facilities. The Libraries possesses an LS2 automated circulation system and is heavily involved in other automation activities. Employment: Librarians have faculty status, privileges, responsibilities, rank of assistant professor or above, and are eligible for tenure. Application: Send letter of application with resume and the names of three references including current supervisor to: Donald C. Hudson, Manager, Administrative Services, University Libraries, University of Oklahoma, Norman, OK 73019. The University of Oklahoma is an equal opportunity, affirmative action employer.

HEAD, SERIALS DEPARTMENT. Duties: Under the general direction of the Director, Library Technical Services, this position is responsible for the management of the Serials Department with approximately 16,000 serial subscriptions; includes supervision and coordination of serials cataloging, periodicals check-in, added volumes/added copies, serials acquisitions, binding, and the Current Periodicals/Microforms Area. Supervises one full-time serials cataloger, eight classified staff, and student assistants; responsible for planning, review and implementation of services, procedures and programs for both the processing and public service areas; coordinates all personnel activities including interviewing, hiring, training, evaluating and staff development; responsible for production of a computer produced serials holdings list; provides reference service in the Current Periodicals/Microforms Area on a regular basis. Qualifications: Required: MLS from ALA-accredited library school; four years technical services experience in a library with at least two years professional serials experience, including cataloging; two or more years supervisory responsibility; significant knovledge and experience with an automated system (RLIN, OCLC or the equivalent), AACR2, LC classification and subject headings; knowledge of at least one European language. Evidence of research and publication. Desirable: Experience in an academic library; demonstrated leadership abilities and supervisory skills; public service experience; strong interpersonal and communication skills; reading knowledge of additional foreign languages; second master's degree and/or additional postgraduate work. Deadline for Applications: January 3, 1989. Available: March 15, 1989. Salary: $\$ 28,000$ minimum. Benefits: TIAA/CREF; State Retirement System; comprehensive medical protection; 21 days vacation; University holidays; generous sick leave. University Libraries: A member of the Research Libraries 
Group and ARL, the University Libraries consist of a main library and six branches. The collections contain more than 2.1 million volumes, 16,000 periodical subscriptions, and three outstanding special collections in history of science, western history, and business history. A major expansion of the main library was completed in May 1982, doubling the size of library facilities. The Libraries possess an LS2 automated circulation system and are heavily involved in other automation activities. Employment: Librarians have faculty status, privileges, responsibilities, rank of assistant professor or above, and are eligible for tenure. Application: Send letter of application with resume and the names of three references including current supervisor to: Donald C. Hudson, Manager, Administrative Services, University Libraries, University of Oklahoma, Norman, OK 73019. The University of Oklahoma is an equal opportunity, affirmative action employer.

INSTRUCTIONAL SERVICES LIBRARIAN. Full-time probationary tenuretrack instructor/assistant professor to coordinate and promote existing bibliographic instruction program; provide instruction and orientation for library users; plan and participate in library public relations program; serve as library liaison for assigned disciplines and provide reference, research and other related assistance to library users. ALA-accredited Master's and demonstrated experience in bibliographic instruction required. Preference will be given to candidates with a science, engineering or business subject expertise. Salary to $\$ 25,000$ for 180 duty days per year. Applications from minorities encouraged. Memorial Library is home to MSUS/PALS, an integrated online library system containing over 1.5 million records, now serving 31 academic libraries in Minnesota and North Dakota. Applications must be postmarked by December 1, 1988. Appointment will be made in early 1989. Apply to: Thomas M. Peischl, Dean of the Library, Mankato State University, MSU Box 19, Mankato, MN 56002.

MUSIC/AV CATALOG LIBRARIAN: Responsible for a full range of cataloging functions, including classification, descriptive cataloging and subject cataloging of music monographs, scores, and audio-visual materials. Revises the work of paraprofessionals working with contributed copy in the same subject area. Required: MLS from an ALA-accredited library school. Preferred: Subject master's in music; knowledge of one or more European languages; familiarity with AACR2, LC Classification and MARC formats; experience with OCLC or other online databases. Salary: Minimum $\$ 18,000$. Send letter of application, resume and names of three references and/or placement file address by December 1, 1988, to: Dennis R. Defa, 328 Marriott Library, University of Utah, Salt Lake City, UT 84112. The University of Utah is an Equal Opportunity, Affirmative Action Employer. Women and minorities are encouraged to apply.

REFERENCE/CIRCULATION LIBRARIAN, The University of Dubuque. Supervises circulation activities, provides reference assistance (including one evening) with primary responsibility for the Theology Library, performs online searching. Assists in active bibliographic instruction program. Participates in collection development, and library planning and automation. Supervises one full-time paraprofessional and 16 students. The Library serves the liberal arts college of approximately 1,200 students, which includes an MBA and an MSN program and approximately 200 students of the Theological Seminary. The University is affiliated with the Presbyterian Church (USA). Qualifications: Required: ALA-accredited MLS. Desired: Theology or religion degree or experience in a theological library. Salary: $\$ 18,000$ minimum. Availability: January 3, 1989. Please submit a letter or application and resume to: Mary Anne Knefel, Interim Director, University of Dubuque Library, Dubuque, IA 52001. The University of Dubuque is an EO/AA Employer. 
REFERENCE LIBRARIAN, Science Emphasis, Moody Memorial Library. Seeking a reference librarian with strengths in science information to join centralized reference department of six professionals. General reference service includes desk coverage (with regular evening and weekend hours), database searching and bibliographic instruction; supervision of microform service. Qualifications: ALA-accredited Master's; science degree; supervisory experience; demonstrated aptitude for working with machines; ability to communicate effectively. Desired Qualifications: Two or more years of professional reference experience; experience with bibliographic instruction; Master's degree in a science; knowledge of database searching. Tenure-track position available at instructor or assistant professor level, dependent upon experience and qualifications. Faculty rank and status. Salary: minimum at instructor level, $\$ 21,600$ for twelve months. Baylor University is a privately supported denominational university of over 11,500 students, with a facultystudent ratio of 1 to 20, located in Waco, Texas, a city of about 104,000, halfway between Dallas and Austin on I-35. Excellent fringe benefits include retirement, health, dental, 20 days vacation. Preference given to applications received before December 31, 1988. Send letter of application, resume, and names and addresses of three current references to: Janet Sheets, Chair, Reference Librarian Search Committee, Moody Memorial Library, BU Box 7148, Waco, TX 76798-7148. Equal Opportunity, Affirmative Action Employer.

REFERENCE LIBRARIAN, SCIENCE \& TECHNOLOGY (entry level, search extended). Provides comprehensive reference assistance with emphasis on the sciences from a centralized reference collection. Prepares bibliographies and guides to the literature for use in staff training and classroom instruction. Assists with bibliographic instruction, computerized reference services, and CDROM search services. Serves as one of seven Reference Division resource librarians in the sciences. Responsible for reference collection development in assigned areas. Qualifications: ALA-MLS. Academic background in the sciences required, preferably in physical or life sciences. Second master's degree in science-related field preferred. Pre-professional library experience and experience with online systems of bibliographic data retrieval desirable. Salary: $\$ 20,000$ for 10.5 months; $\$ 21,000$ with additional master's. Benefits: Competitive benefits package. No state income tax. Faculty rank. Closing Date: Applications received by December 12, 1988 will receive first consideration. Write or call for complete description of duties, qualifications, and benefits. To apply, send letter of application, resume and names to: Personnel Operations, Evans Library, Texas A\&M University, College Station, TX 77843-5000. Phone: (409) 845-8111. AA, EEO employer.

THREE POSITIONS. Cataloging Opportunities at Texas A\&M University: 1) Original Cataloger (entry level): Responsible for cataloging and classifying monographic materials in all languages, subjects and formats. Performs original cataloging, editing of subject headings, classification and descriptive cataloging on OCLC. Qualifications: ALA-MLS. Entry level (no post-MLS experience). Prefer pre-professional monographic cataloging experience with AACR2 and LC Classification and subject headings. Experience with OCLC cataloging system and name authority file highly desirable. Demonstrated ability to handle detailed work. Salary: $\$ 20,000$ for 10.5 months; $\$ 21,000$ with additional masters. 2) Head, Automated Cataloging Department (search extended): Provides overall supervision and management for the automated cataloging department under the direction of the head, processing division. Responsible for copy cataloging, NOTIS database and card catalog maintenance, maintaining online authority files and solving authority problems, and marking and labeling of materials. Participates in weekly planning meetings. Department consists of 27 classified staff. Qualifications: 
planning meetings. Department consists of 27 classified staff. Qualifications: ALA-MLS. Minimum of 3 years progressively responsible, professional (postMLS) cataloging experience, preferably in an online environment. Demonstrated supervisory skills. Knowledge of MARC formats, AACR2, LC rule interpretations, and Library of Congress subject headings required. Must have experience with OCLC or similar bibliographic utility. Experience with NOTIS desirable. Salary: $\$ 23,000$ minimum for 10.5 months; $\$ 24,000$ with additional master's. 3) Head, Original Cataloging Department. Provides overall supervision and management for the original cataloging department under the direction of the head, processing division. Department is responsible for all original cataloging for all formats in all languages, and provides descriptive cataloging, LC classification, and LC subject headings as needed for OCLC member-input records. Participates in weekly planning meetings. Department consists of 4 entry-level professional librarians, 2 experienced catalogers, and 4.5 classified staff. Qualifications: ALA-MLS. Minimum 4 years progressively responsible professional (post-MLS) cataloging experience, preferably in an online environment. Require at least one year in an academic or large research library. Experience with MARC formats, AACR2, LC rule interpretations, and Library of Congress subject headings. Must have experience with OCLC or similar bibliographic utility. Experience with NOTIS desirable. Supervisory and management skills appropriate to the position. Salary: $\$ 24,000$ minimum for 10.5 months; $\$ 25,000$ with additional master's. Benefits: Competitive benefits package. No state income tax. Faculty rank. Texas A\&M is located in Bryan/College Station, between Austin and Houston. Closing Date: Applications received by December 12, 1988, will receive first consideration. Write or call for complete description of duties, qualifications and benefits. To apply, send letter of application, resume and names and telephone numbers of three professional references to: Roberta Pitts, Head, Personnel Operations, Evans Library, Texas A\&M University, College Station, TX 77843-5000. Phone: (409) 845-8111. AA, EEO employer.

TWO POSITIONS. Administrative opportunities at Texas A\&M University. 1) Head, Resource Development Division: Responsible for planning, administration, evaluation and coordination of collection development activities. Initiates, develops, supervises and manages selection of materials, approval plans, gift and exchanges, serial and monograph searching, preservation, selected grants, special projects and collection analysis. Allocates and monitors the use of $\$ 2.8$ million materials budget. Develops cooperative program with academic departmental library representatives. Supervises 3 professional librarians and 10 support staff. Qualifications: ALA-MLS. Minimum six years professional (post MLS) experience, preferably in an academic library. Supervisory experience required. Extensive knowledge of current collection management issues and procedures required. Knowledge of library automation as it relates to collection management, prefer familiarity with OCLC, working knowledge of foreign language sources and book trade. Salary: $\$ 32,000$ minimum for 12 months; $\$ 33,000$ with additional masters. 2) Head, Documents Division: Coordinate reference service, collection development, processing, circulation and administration operations for Division. Define goals, establish objectives and formulate policy. Supervise and train 3.5 professional librarians and 6 support staff. Oversee the U.S., Texas and Patent Depository Program. Provide comprehensive reference service through indexes, online and CD-ROM databases. Develop user instruction programs; conduct tours. Implement addition of bibliographic records to NOTIS for three collections: U.S. Documents, Texas Documents and Technical Reports. Qualifications: ALAMLS. Minimum of six years professional experience required, preferably in an academic library. Experience in government documents required. Supervisory experience required. Ability to analyze problems, identify viable solutions, set objectives and contribute to overall library planning. Should possess knowledge 
of issues and trends associated with government publications. Knowledge of OCLC or other automated bibliographic control system. Strong communication and interpersonal skills. Salary: $\$ 32,000$ minimum for 12 months; $\$ 33,000$ with additional masters. Benefits: Competitive benefits package. No state income tax. Faculty rank. Texas A\&M is located in Bryan/College Station between Austin and Houston. Closing Date: Applications received by December 12,1988 , will receive first consideration. Write or call for complete description of duties, qualifications and benefits. To apply, send letter of application, resume and names and telephone numbers of three professional references to: Roberta Pitts, Head, Personnel Operations, Evans Library, Texas A\&M University, College Station, TX 77843-5000. Phone: (409) 845-8111. AA, EEO employer.

UNIVERSITY LIBRARIAN. The University of Evansville invites applications and nominations for the position of University Librarian. The University Librarian is responsible for providing leadership and direction for all learning resources on campus and serves as a member of the Academic Affairs Council. The successful candidate must have demonstrated administrative capabilities in a college or university library. Communications and interpersonal skills, strong service orientation, and ability to work effectively with faculty and colleagues are essential. ALA-accredited degree required, Ph.D. preferred. The University of Evansville is a fully-accredited, private university located in a city of 135,000 in southwestern Indiana. Enrollment numbers 3,400 full- and parttime students. The library completed a major addition and renovation in 1986 and is fully automated using the NOTIS system. Salary commensurate with qualifications and experience. Send application and resume no later than December 1, 1988, to: University Librarian Search Committee, Office of Vice President for Academic Affairs, University of Evansville, 1800 Lincoln Avenue, Evansville, IN 47722. Affirmative Action Employer.

\section{LOOKING FOR A JOB?}

ACRL's Fast Job Listing Service brings you job notices four weeks before they appear in College \& Research Libraries News. This monthly bulletin also contains job postings that, because of narrow application deadlines, do not appear in $C \& R L N e w s$.

The Fast Job Listing Service is sent to subscribers by first-class mail the first week of every month. You can be a step ahead of other job applicants by seeing position descriptions very shortly after they are received in our office.

Subscriptions to the Fast Job Listing Service are for a period of six months-by that time we hope you have found the job you're looking for! The cost is $\$ 10$ for ACRL members and $\$ 15$ for non-members.

You may use the form below to enter your subscription.

YES! I want to see job notices as quickly as possible by subscribing to ACRL's Fast Job Listing Service.

I am a member of ACRL and am enclosing \$10.

I am not a member of ACRL and am enclosing \$15.

NAME:

ADDRESS:

CITY/STATE/ZIP:

Please make checks payable to ACRL/ALA and send to the Fast Job Listing Service, ACRL/ALA, 50 E. Huron Street, Chicago, IL 60611. 


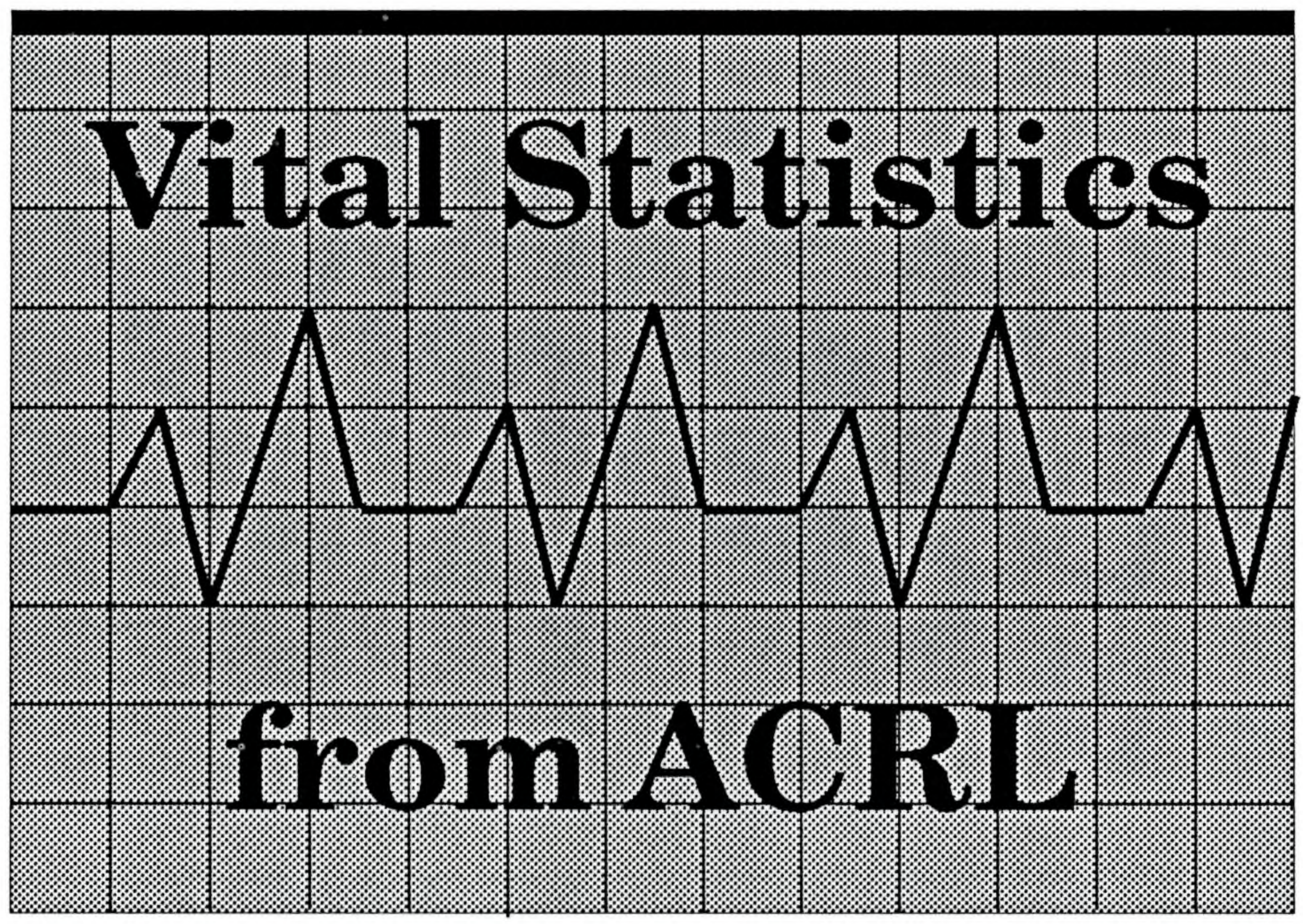

Library Statistics of Colleges and Universities, 1985:

National Summaries, State Summaries, Institutional Tables. Statistics on 3,000 academic libraries surveyed by the Center for Educational Statistics. Contains data on collections, operating expenditures, staff, and institutional indices of library operating expenditures, books and bound serials and FTE library staff. $\$ 30.00 \mathrm{pb} ;$ ACRL member $\$ 24.00 \quad 240$ p. $\quad 0-8389-7147-4 \quad 1987$

ACRL University Library Statistics 1985-86 and 1986 "100 Libraries" Statistical Survey. Data and rankings of 149 university, college, community and junior college libraries on collections, expenditures, personnel, and interlibrary loans.

$\$ 30.00 \mathrm{pb} ;$ ACRL member $\$ 24.00 \quad 110 \mathrm{p}$. $\quad 0-8389-7144-\mathrm{x} \quad 1987$

Quantitative Criteria for Academic Research Libraries, by Kendon L. Stubbs. Data from 3,000 academic libraries answers the question, "What is an academic research library?" In tables arranged by state, each institution is ranked by a component score. $\$ 19.00 \mathrm{pb} ; \quad$ ACRL member $\$ 15.00$ 135p. $\quad 0-8389-6788-41984$

Association of College and Research Libraries A division of the American Library Association c/o ALA Publishing Services, Order Department 50 East Huron Street • Chicago, Illinois 60611-2795 


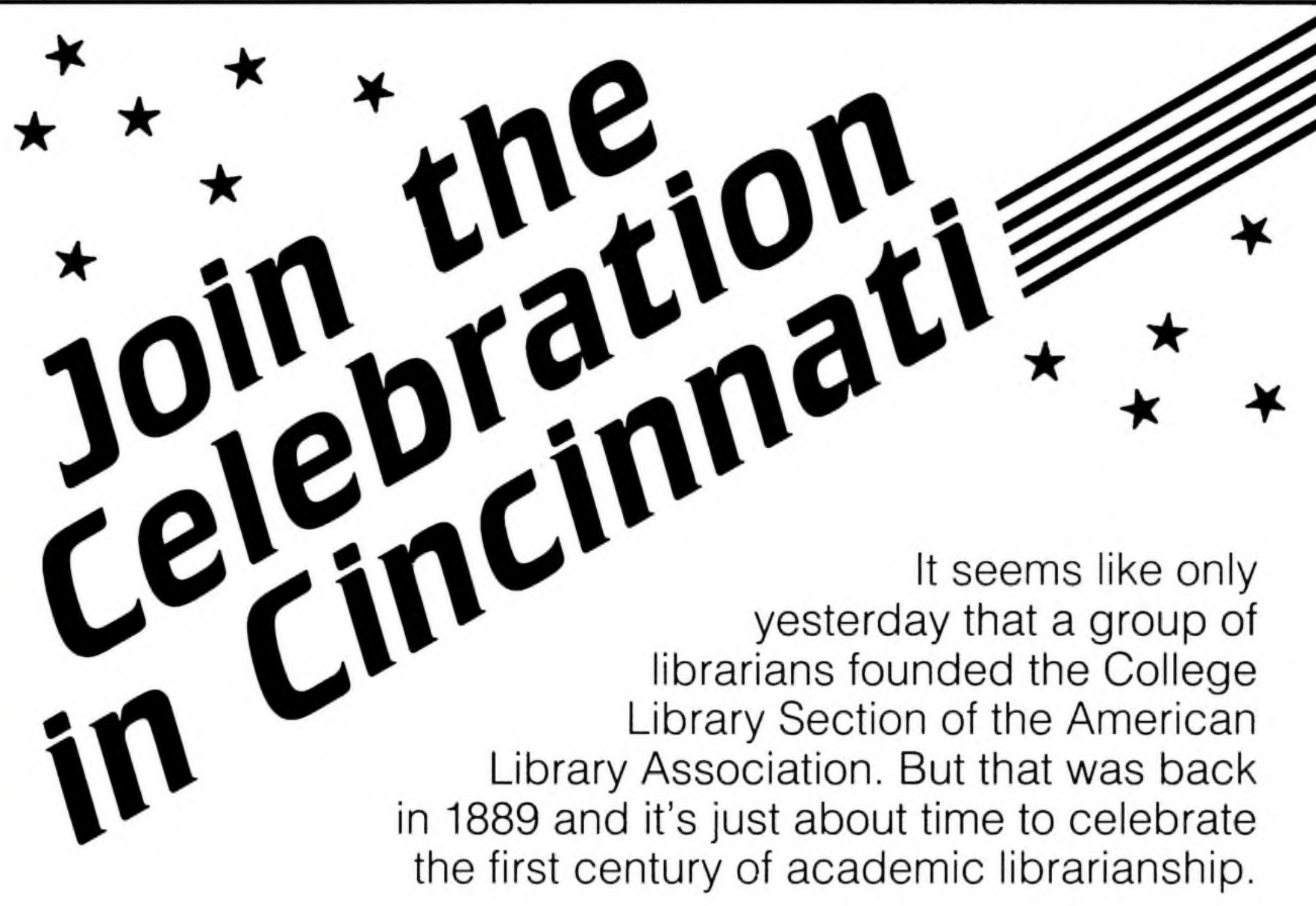

The celebration begins at the ACRL Fifth National Conference, April 5-8, 1989 in Cincinnati, Ohio. The program features major speakers from higher education, technology and publishing. The best in library research will be presented by over 50 contributed paper authors. Panel presentations, small group discussions, poster sessions, exhibits and preconferences round out the conference.

There will be plenty of opportunities to meet old friends and new. Meet distinguished past ACRL presidents and executive directors at a luncheon in their honor. And help blow out the one hundred candles on the cake at the allconference reception!

The second century of academic librarianship begins in Cincinnati on April 5, 1989.

\section{For conference information contact:}

Fifth National Conference Association of College and Research Libraries 50 East Huron Street Chicago, IL 60611 (312) 944-6780, ext. 291

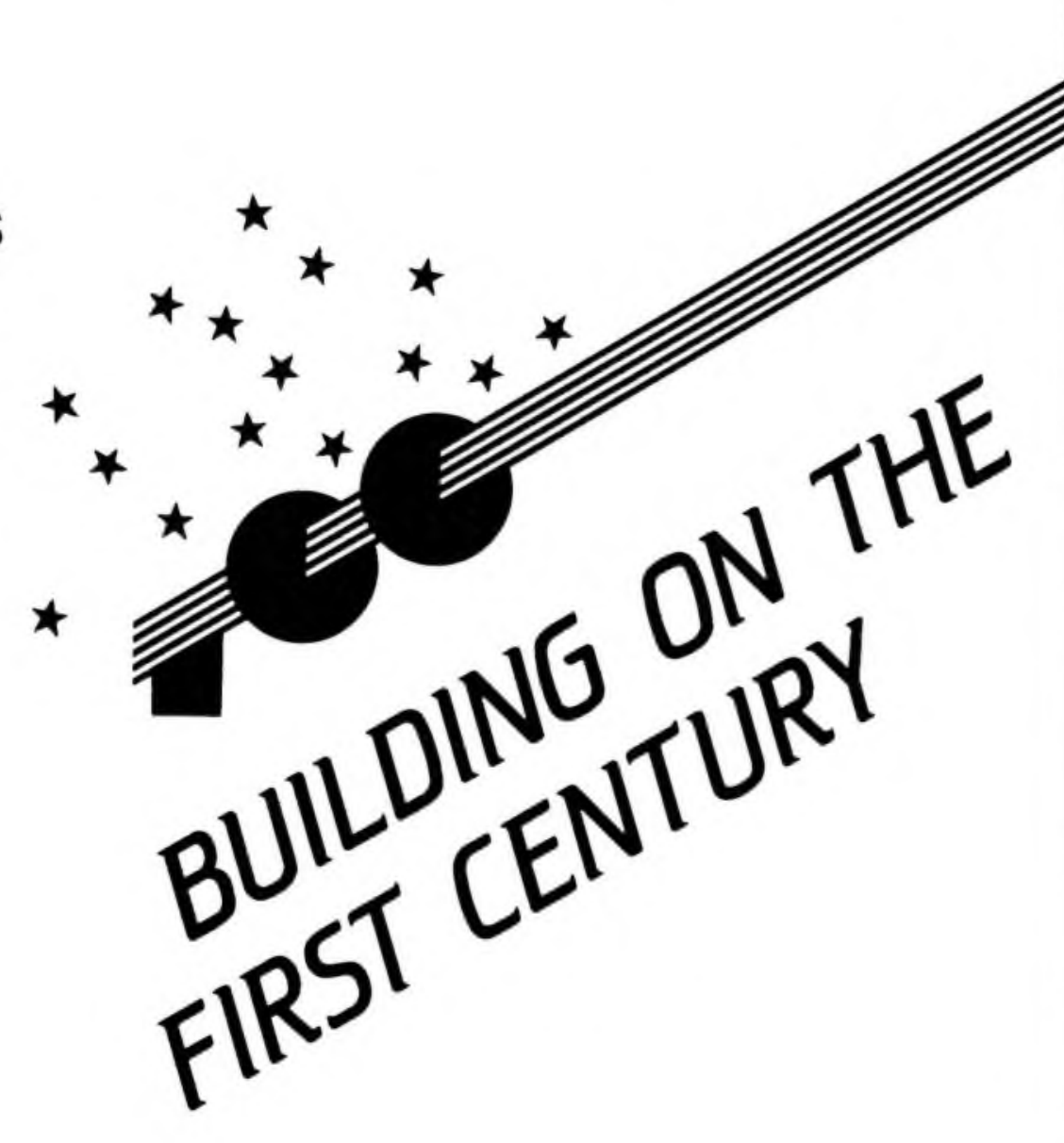




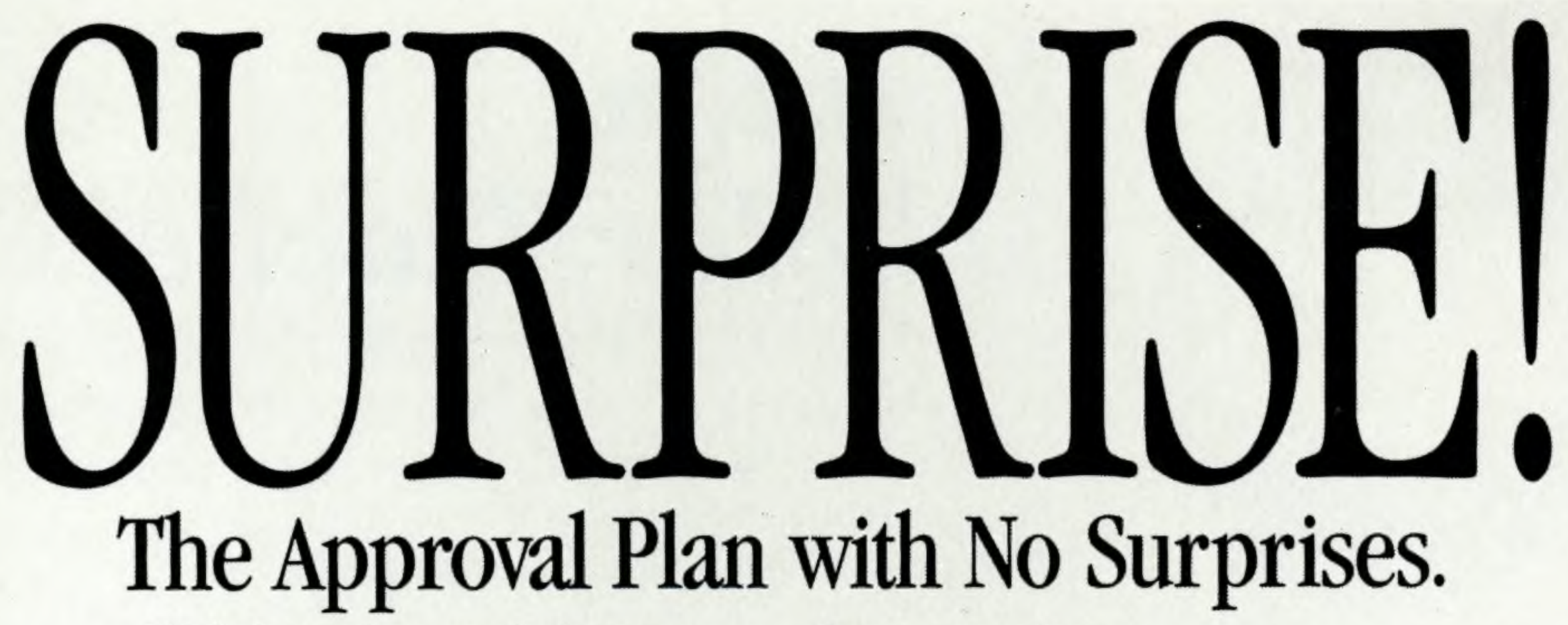

Old-fashioned approval plans are designed for the book budgets of the 1960s. Too often they surprise you with unpredictable performance, high returns, and unforeseen cost fluctuations.

In contrast, we put librarians firmly back in control of the books they are receiving and the money

they are spending.

Our approval plans feature prepublication title notification, personally selected (not computer-selected) books, a carefully defined list of publishers, and management reports that really help you control future approval activity.

Call or write us for more information

Academic Book Center 5600 NE Hassalo Street Portland, OR 97213 $1-800-547-7704$ 503-287-6657

Scholarly Book Center 451 Greenwich Street New York, NY 10013 1-800-223-4442 212-226-0707 


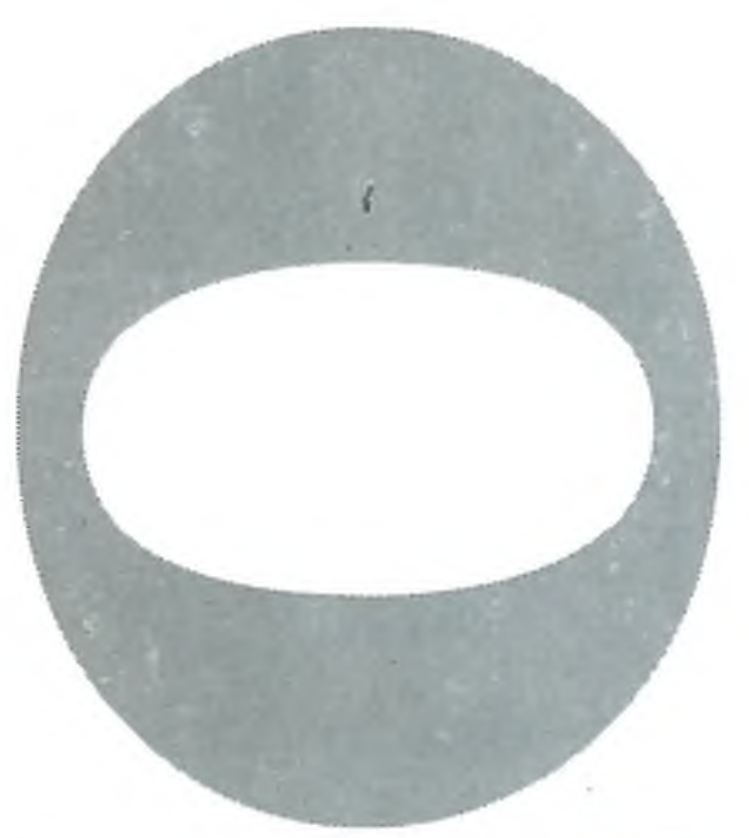

\section{Eminent}

\section{Scholar/Teachers}

\section{"Every American - in or out of school - by means of a VCR or a library or television station that shows the Eminent Scholar/Teachers series now has access to the faculties of leading universities."}

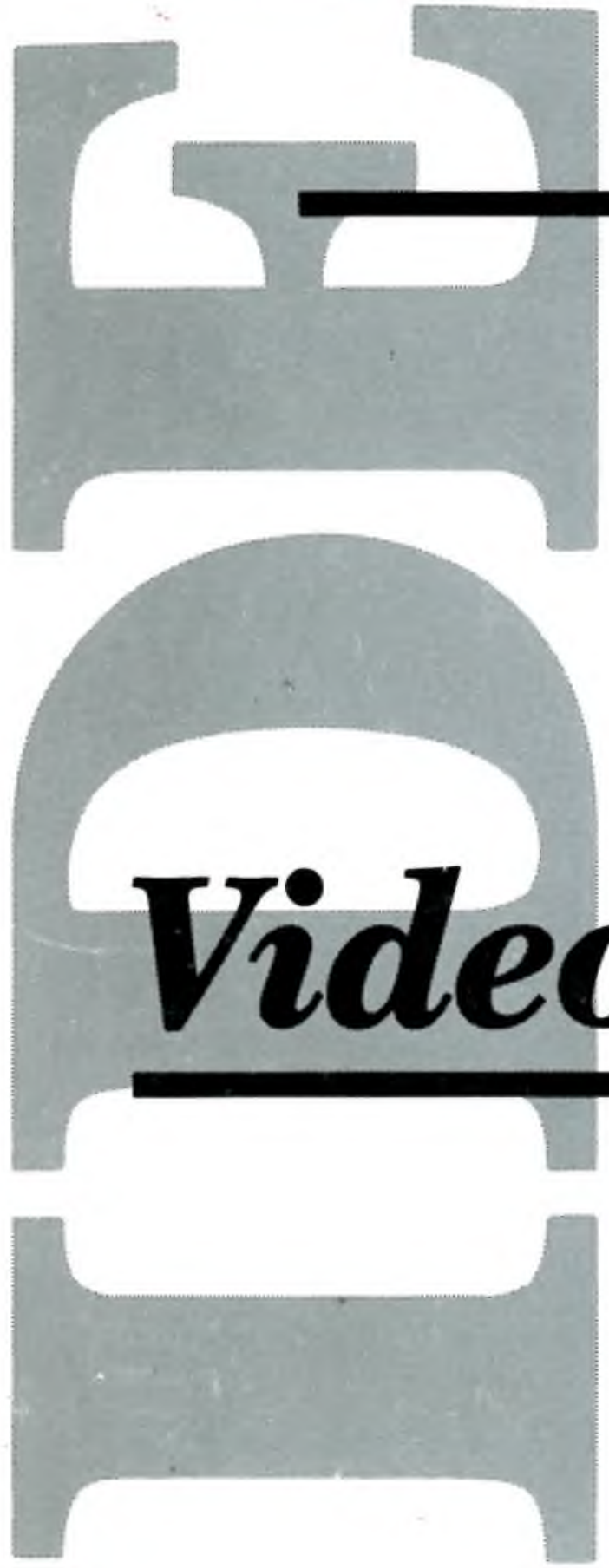

\section{Modern American Literature Syllabus}

This series treats the main currents of literary activity, major authors, and key works in America between 1900 and World War II. It provides necessary backgrounds and positions the authors and their works in the context of American literary history.

All videotapes are accompanied by printed lecture guides; student and instructor's handbooks, manuals, and course companions will also be available. Individual videotapes $\$ 85.00$. Standing order for complete series, $5 \%$ discount.
Ernest Hemingway's Fiction Dreiser's Sister Carrie

Alfred Kazin

(City University of New York)

William Faulkner's Fiction As I Lay Dying

Cleanth Brooks (Yale University)

John Dos Passos's Fiction

U.S.A.

Townsend Ludington (University of North Carolina-Chapel Hill)

Richard Wright's Fiction Black American Literature Valerie Smith (Princeton University)

\section{Lecture}

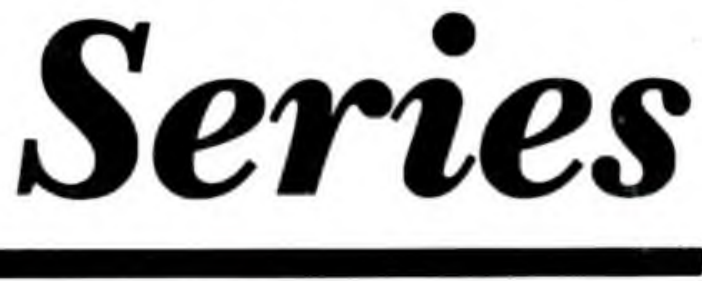

Documented videotape lectures by master educators

Edith Wharton's Fiction

The House of Mirth

R.W.B. Lewis (Yale University)

Theodore Dreiser's Fiction

Realism and Naturalism in

American Literature

Warner Berthoff (Harvard University)

\section{Robert Frost's Poetry}

Modern American Poetry

Helen Vendler (Harvard University)

T.S. Eliot's Poetry

The Waste Land

A. Walton Litz (Princeton University)

F. Scott Fitzgerald's Fiction

The Great Gatsby

The Profession of Authorship in America

Matthew J. Bruccoli

(University of South Carolina)
Thomas Wolfe's Fiction

Look Homeward, Angel

The Southern Literary Renaissance

Louis D. Rubin, Jr. (University of North Carolina-Chapel Hill)

John Steinbeck's Fiction

The Grapes of Wrath

Jackson Benson

(San Diego State University)

Hemingway's A Farewell to Arms American Literature of the Twenties Michael Reynolds

(North Carolina State University)

American Literature of the Thirties American Literature and Politics Leslie Fiedler

(State University of New York-Buffalo)

American Literature of World War II The Modern American Novel

George Garrett (University of Virginia) 